\title{
Innovations in the design of sewage treatment plants-A review
}

\author{
Fatema Abdullah Said Al \\ Maawali \\ Ryan Said Abdullah Saif Al- \\ Sheidi \\ Mayasah Saud Nasser Al Risi \\ Fatema Ali Muhammed Al \\ Balushi \\ Dr. Binumol Shahulhameed
}

\author{
Shinas College of Technology \\ Shinas College of Technology \\ Shinas College of Technology \\ Shinas College of Technology \\ Shinas College of Technology
}

\begin{abstract}
Rapid growth in the population and development of cities led to the increase in the quantity of waste water which in turn causes critical environmental issues. Management of wastewater and sludge will affect economic growth of any nation and challenges associated led to the research in this field. Innovative methods for sewage treatment were developed in many countries to solve the problems arising as a result of enormous production in waste water and sludge. Different approaches and techniques were evolved as a result of the studies conducted in order to attain a unique solution for maintaining a safe environment. The main aim of this paper is to provide details regarding the various researches in planning and design of sewerage systems in Oman. Various regulations in the treatment of waste water and sludge as well as policies adopted for the management are discussed in detail. Based on the discussions and related review, it is clear that over decades the sewage treatment is considered to be a major issue in Oman. Further, applications related to the better utilization of the wastewater and the sludge in agriculture and other related fields are in progress in various parts of Oman. Research projects were ongoing in different universities of Oman on the sustainable utilization of the waste products and innovative methods to be adopted in the sewage treatment process.
\end{abstract}

\section{Introduction}

Environmental pollution happens when elements cannot be destroyed without harming or damaging the environment and these elements are not produced by nature. In other words, pollution is caused when the nature can't destroy or decomposed these unnatural elements. Pollution is a serious problem threating the life of the planet including human beings, animals, plants and specially the essential elements of life like water and air. One of the pollution types that have significantly negative effects on the planet life is water pollution. Water pollution is defined as the presents of wastes in ground water, which can cause serious effect and sometimes can be fatal to human life, animals and plants.

Sewage treatment is the process of removing contaminants such as organic matter, suspended solids, pathogens, nutrients, and toxic chemicals like heavy metal and pesticides from wastewater. All drains in the city lead to wastewater treatment plants, where this water get turned back into useful water. it's an engineering process that makes dirty water clean. It all starts from houses, commercial and industrial places ending up to the sewage treatment plant.

The removal of these contaminates can be done by physical, biological or chemical processes aimed to produce environmentally safe sewage water suitable to be disposed or reused for the agricultural uses or maybe use it as fuel. Our study focuses on the characteristics of wastewater. Our aim is to take water sample from water treatment plant located in Shinas college of technology, to study its 


\section{Journal of Student Research}

Fourth Middle East College Student Research Conference, Muscat, Sultanate of Oman

characteristics by conducting some tests like $\mathrm{pH}$ test for measuring the $\mathrm{pH}$ value of the water, alkalinity, acidity, measuring turbidity of the water and DO -dissolved oxygen- and more.

The objective of wastewater treatment is to remove pollutants, toxicants and nutrients exist in water that can cause dangerous problems. This wastewater treatment work on making the quality of water much better and healthier for reusing it after in very different aspects of life. The wastewater collected in the treatment plants comes from domestic use of water from toilets, showers, bath, sinks and more that have been disposed of into sewers. The disposed water not only comes from household waste, it also comes from industrial and commercial water use that will end up in the sewer treatment plants carried by sewers drain.

Various objectives considered for the present study includes

1. Physical, chemical and biological characteristics of a wastewater sample collected from our college's water treatment plant - "Shinas College of technology".

2. Comparing results with prescribed standards.

3. Review of related studies and discussions regarding any modifications needed.

Wastewater treatment and sludge management in Saltanat of Oman are evolving over the years. Sludge employment was a challenge due to assembly with human waste. Sludge and wastewater employment can add to positively in the economic sides of the country in type of create job and improving yearly incoming rate. Numbers of the research project did on wastewater reuse and other outstanding ones related to ground application of sewage sludge. A amendment of existing standard, regulation, and policies for the management and useful use of sewage sludge in Sultanate of Oman (Suaad Jaffar et al., 2017). Niraj S et al. (2011) conducted studies on wastewater administration and care of the environment. Depend on the nature of the wastewater; it is proposed if whether primary, secondary and tertiary treatment will be carried out before last disposal. Developed a suitable procedure for definition of passable criteria for residues.

\section{Review of literature on waste water treatment process}

In the Sultanate of Oman, the majority of cities use septic and holding tanks to collect sewage water from residential areas. Many of these tanks quickly become overloaded due to inadequate construction and maintenance. Sewage from these tanks is transferred by municipal trucks to the closest sewage treatment plants (STP) or sometimes is discharged to nearby wadis (dry channel beds). The capital city Muscat is being fully connected to a piped sewer network, and the expectation is that a large amount of treated wastewater and sludge will be generated as a consequence. Proper planning and management of such resources will help to some extent to alleviate the acute water shortage problem of the country (Choudri et al., 2015). It was reported in 2010 that only $20 \%$ of Muscat's individuals were connected to the sewage network, and with the implementation of sewage network project at the end of 2015, Haya Water has connected $86 \%$ of Muscat's population to the sewer system (Zekri et al., 2014).

The treated wastewater reuse plays an important role in the management of water resources and environment, economic, and social aspects of a country. The wastewater projects in Oman are considered a significant element of all new developments. This section introduces the activities of Omani Wastewater Services Company, which is implementing a new sewage system in the Muscat Governorate. Oman has the capacity to accommodate the sludge generated each year. According to Alkhamisi (2013), agricultural land in Oman under cultivation is recorded at 72,299 ha. Fruits occupy the highest amount of land at 53\%, then perennial forages (30\%), followed by vegetables $(11 \%)$ and finally field crops $(6 \%)$. The highest total production in tons is from perennial forages $(58 \%)$, then fruits (23\%), vegetables (17\%), and grain crops $(2 \%)$.

Growing attention about environmental impact of wastewater discharge .Increasing regulatory and 


\section{Journal of Student Research}

technological benefit in water recycles and reuse. Obtainable conventional water and wastewater treatment technique, like precipitation, stripping, adsorption, membrane filtration, etc., don't ruin environmental contaminant. Implementation of free radical chemistry for the water treat, wastewater and serious waste have been focused (Dr. Ahmed,2017).

\section{Experimental studies}

Studies were conducted in the quality of sewage sample collected from the sewage treatment plant before any process as well as the quality of waster sample after treatment process.

Preliminary tests on water sample include:

- Measurement of PH value

- Measurement of alkalinity

- Determination of turbidity

- Determination of acidity

For measuring the $\mathrm{pH}$ value of sample of water a ph meter was used. The specimen of water was kept in a beaker and the two' electrodes of the instrument are dipped in water connected to a dry cell. The current passing through the circuit indicates the $\mathrm{pH}$ value which is read directly on the dial.

The section 1 should be succinct, with no subheadings, and should present the background information necessary to

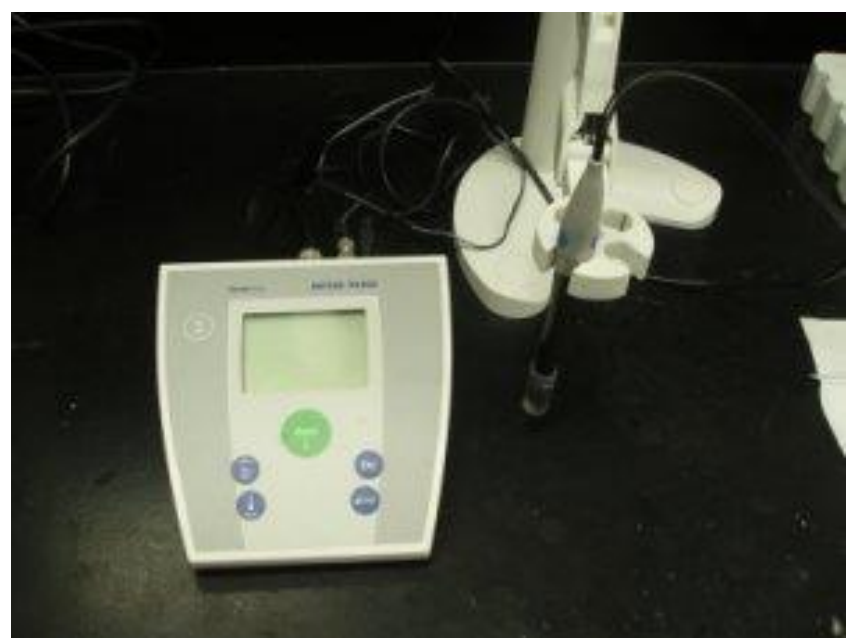

Figure 1. $P H$ meter

Then turbidity is measured by using a turbidimeter shown in figure 2 . The hardness of water is due to the presence of certain salts, such as carbonates, bi-carbonates, chlorides and sulphates, of calcium and magnesium, dissolved in it. Calcium and magnesium salt are soap destroying and therefore the prime constituents concerned with hardness. 


\section{Journal of Student Research}

Fourth Middle East College Student Research Conference, Muscat, Sultanate of Oman

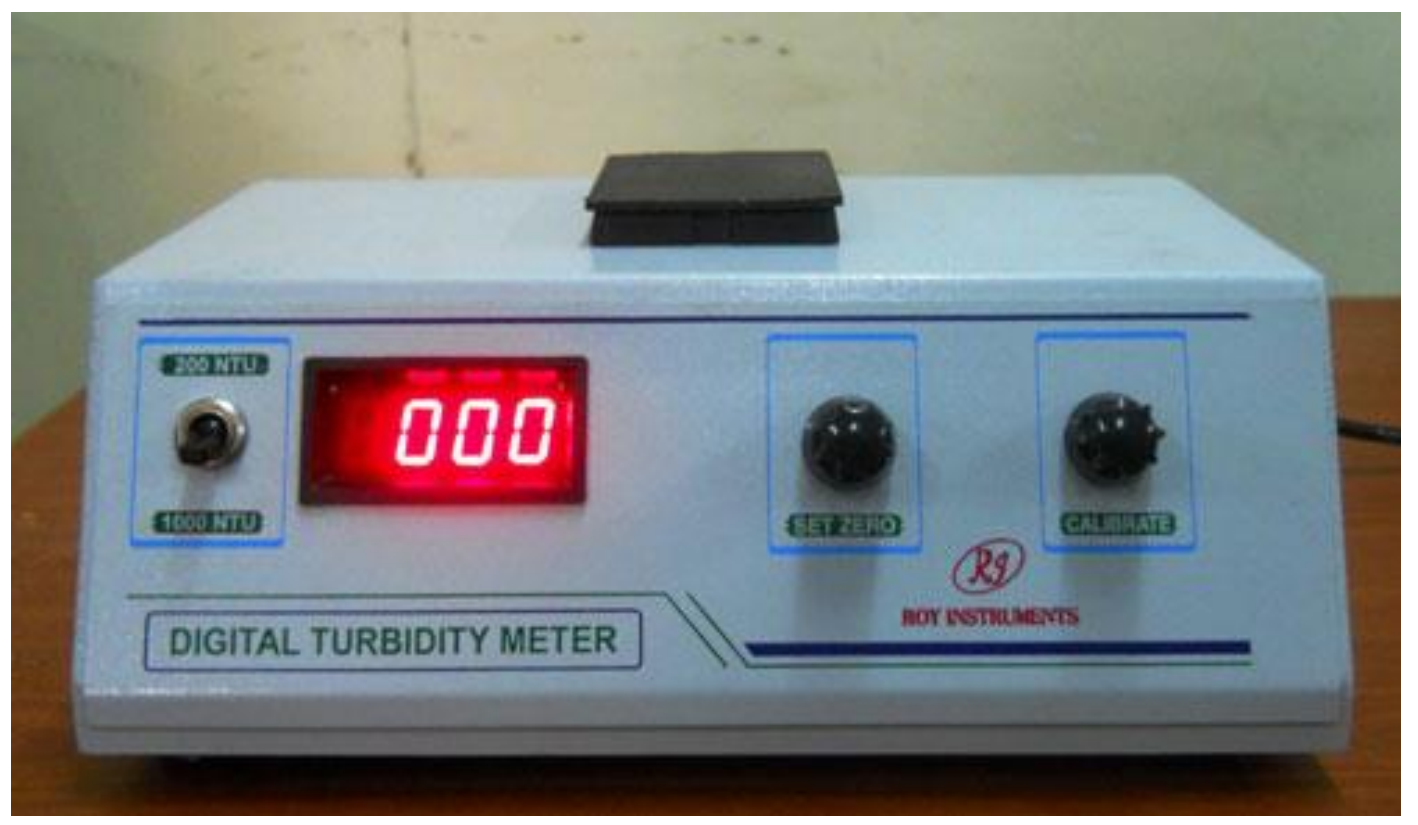

Figure 2. Turbidimeter

Figure 3. Waste water treatment plant at Shinas College of Technology, Oman

Figure 3 shows the various stages of treatment of waste water in the existing wastewater traetment plant at Shinas College of Technology, Oman. After treatment process water is utilized for watering plants and other purposes. Figure 4shows the quality of water after and before treatment process.

Figure 4. Quality of water before and after treatment process

\section{Results}

Table 1 shows the quality of water before treatment process. Tests were conducted in the chemistry lab at Shinas College of Technology. Different parameters such as Turbidity, Hardness, $\mathrm{PH}$, Chloride, Total solids and Alkalinity were determined. Also biological properties such as BOD, COD, Ecoli etc were also determined

\begin{tabular}{|l|l|l|}
\hline Parameters & Before treatment & Permissible limit \\
\hline Turbidity & $10.1 \mathrm{NTU}$ & $5 \mathrm{NTU}$ \\
\hline $\mathrm{pH}$ & 7.3 & $6.5-8.5$ \\
\hline Hardness & $530 \mathrm{mg} / \mathrm{l}$ & $300 \mathrm{mg} / \mathrm{l}$ \\
\hline Chloride & $630 \mathrm{mg} / \mathrm{l}$ & $250 \mathrm{mg} / \mathrm{l}$ \\
\hline alkalinity & $177 \mathrm{mg} / \mathrm{l}$ & $200 \mathrm{mg} / \mathrm{l}$ \\
\hline BOD & $18 \mathrm{mg} / \mathrm{l}$ & $6 \mathrm{mg} / \mathrm{l}$ \\
\hline COD & $30 \mathrm{mg} / \mathrm{l}$ & $10 \mathrm{mg} / \mathrm{l}$ \\
\hline E-Coli & 810 & nil \\
\hline Total solids & $635 \mathrm{mg} / \mathrm{l}$ & $500 \mathrm{mg} / \mathrm{l}$ \\
\hline
\end{tabular}

Table 1. Quality of water before treatment

Table 2 shows the quality of water after treatment along with the standard values. Similar tests were conducted to find out the values of parameters after treatment process. 
Journal of Student Research

Fourth Middle East College Student Research Conference, Muscat, Sultanate of Oman

\begin{tabular}{|l|l|l|}
\hline Parameters & After treatment & Permissible limit \\
\hline Turbidity & $4.5 \mathrm{NTU}$ & $5 \mathrm{NTU}$ \\
\hline $\mathrm{pH}$ & 7.3 & $6.5-8.5$ \\
\hline Hardness & $350 \mathrm{mg} / \mathrm{l}$ & $300 \mathrm{mg} / \mathrm{l}$ \\
\hline Chloride & $240 \mathrm{mg} / \mathrm{l}$ & $250 \mathrm{mg} / \mathrm{l}$ \\
\hline alkalinity & $146 \mathrm{mg} / \mathrm{l}$ & $200 \mathrm{mg} / \mathrm{l}$ \\
\hline BOD & $6.2 \mathrm{mg} / \mathrm{l}$ & $6 \mathrm{mg} / \mathrm{l}$ \\
\hline COD & $13 \mathrm{mg} / \mathrm{l}$ & $10 \mathrm{mg} / \mathrm{l}$ \\
\hline E-Coli & 100 & $\mathrm{nil}$ \\
\hline Total solids & $560 \mathrm{mg} / \mathrm{l}$ & $500 \mathrm{mg} / \mathrm{l}$ \\
\hline
\end{tabular}

Table 2. Quality of water aftere treatment

\section{Conclusion}

From the results it was clear that the quality of waste water before treatment is bad in condition and cannot be used in any of the purposes and cannot be disposed directly into the ground. Values of parameters such as Turbidity, hardness are more compared to the standard values of water. Also biological properties such as BOD, COD, and Ecoli etc were found to be very high compared to the standard values. Hence it cannot be disposed directly to the open spaces without any treatment.

After treatment process available present the values were found to be improved and can be utilized for purposes like watering plants, washing cars and other services.

\section{Acknowledgements}

We take this opportunity to acknowledge the contribution of Dr.Mahmoud Khazalah, Head of the Civil Section, Shinas College of Technology and Dr. Ahmed Abdullah Mohammed Al Balushi, Head of the Engineering Department for their full support and assistance during the development of the project. It is our immense pleasure to express our sincere thanks to the college management specially Dr. Ahmed Mohammed AlMamari, Dean of the College for being constant source of motivation and for his mentorship. .

\section{References}

Abdelrahman, H.A., S. Alkhamisi, M. Ahmed, and H. Ali. (2011). "Effects of treated wastewater irrigation on element concentrations in soil and maize plants". Commun. Soil Sci. Plant Anal. 42:2046-63.

Ahmed, M., S.A. Prathapar, A. Al-Belushi, M. Al-Haddabi, andA. Al-Busiadi. 2003. Greywater reuse potential in Oman. Proceedings of 28th International Hydrology and Water Resources Symposium.

Baawain, M.S., A. Al-Omari, and B.S. Choudri.( 2014) "Characterization of domestic wastewater treatment in oman from three different regions and current implications of treated effluents". Environ. Monit. Assess. 86(5):2701-16.

Harrison, E.Z., S.R. Oakes, M. Hysell, and A. Hay. 2006.

Organic chemicals in sewage sludges. Sci. Total Environ.367:481-97.

Mott Macdonald. 1991. Preparation of wastewater master plans for nine towns. Muscat, Sultanate of Oman: Ministry of Regional Municipalities and Water Resources 
Prathapar, S.A., M. Ahmed, S. Al-Adawi, and S. Al-Sidairi. 2004. Variation in quality and quantity of greywater produced at two mosques in Oman. Proceedings of Wastewater Conference, Salalah,

Prathapar, S.A., M. Ahmed, S. Al-Adawi, and S. Al-Sidairi. Design, construction and evaluation of an ablution water treatment unit in Oman: A case 2006study. Int. J. Environ.Stud, 63(3):283-92.

Suaad Jaffar Abdul Khaliq, Mushtaque Ahmed, Malik Al-Wardy, Ahmed Al-Busaidi \& B.S. Choudri (2017). "Wastewater and sludge management and research in Oman: An overview" Journal of the Air \& Waste Management Association, 67:3, 267-278 